\title{
New Mindset of Entrepreneurs to Create a New Business World
}

\author{
Ms. Sona Pandey \\ Founder \& Owner \\ Grace Ladies \& Professional Skill Development Hub (PSD-HUB) \\ Singapore \& India
}

\begin{abstract}
This research article highlights the new entrepreneurship mindset concepts that an entrepreneur must adopt to move from the traditional business approach to the advanced business approach. The author of this article is an experienced global entrepreneur and the article originated from her own entrepreneur mindset with lots of new business approaches and real time implementations. The entrepreneurship is a fast-paced, constantly changing sphere - one where only the strongest entrepreneurs survive and grow. It takes a truly unique person to jump into this sphere, confident and determined with new mindset. It is a common thought about entrepreneurs that "Entrepreneurs are all different. They all have a different entrepreneur mindset that contributes to their success", in this research article there is description with explanation about new mindset of entrepreneurs which has the similar approach to grow together.
\end{abstract}

Keywords: New Entrepreneurial Mindset, Entrepreneurship, Young Entrepreneurs, Women Entrepreneurs and Global Entrepreneurs.

\section{Introduction}

As a means of getting the entrepreneurs prepared for current and future growth, they are encouraged to learn and start-up with new concepts and mindset of entrepreneurship that can aid them in acquiring the required skills and knowledge which will make them best fit into the global business market without much stress, especially with their own passionate skills. In this case, new mindset of entrepreneurship has been identified. Entrepreneurship is the most effective approach for continuous growth of any country. The entrepreneurial activities significantly affect the economy of an area by building the economic roadmap and providing jobs. Drucker in 1970 believed that what entrepreneurs have in common is not personality traits but a commitment to innovation. According to Aruwa, it is the ability of some people to accept risk and combine factors of production in order to produce goods and services. It can also be seen as the willingness and ability of an individual to seek out investment opportunities in an environment, and be able to 
establish and run an enterprise successfully based on the identified opportunities (Aruwa, 2004).

The World Bank Report in 2012 prepared by Valerio, Parton and Robb argued that assessing entrepreneurial training programs needs to involve both an individual's competencies (entrepreneurial capabilities such as management skills and technical knowledge) and an individual's personal characteristics (an entrepreneurial mindset that includes traits such as resilience and creativity and social-emotional skills such as self-confidence and leadership). Fundamentally, entrepreneurs believe that change is possible, a view that is similar to Dweck's 'incremental mindset', the idea that core qualities can be developed (Dweck, 2012). Entrepreneurship is an individual's ability to turn ideas into action, which includes creativity, innovation and risk taking, as well as the ability to plan and manage projects in order to achieve objectives. This supports everyone in day-to-day life at home and in society, makes employees more aware of the context of their work and better able to seize opportunities and provides a foundation for entrepreneurs establishing a social or commercial activity (European Commission, 2005).

Interestingly, entrepreneurship is the implementation of an individual's talent in the resources in which he or she is available with; and expanding these resources in the future so that one can get individual as well as general i.e. social success. It comes from the French verb 'entreprendre' which means 'to undertake.' Entrepreneurship is the act and art of being an entrepreneur or one who undertakes innovations or introducing new things, finance and business acumen in an effort to transform innovations into economic goods. This may result in new organizations or be part of revitalizing mature organizations in response to a perceived opportunity (Haidar, 2012).Evidences from Universities in the developed countries showed that entrepreneurial education has the potential to transfer and communicate to students the skills, ability and knowledge necessary for them to be able to identify potential business opportunities (Moses \& Mosunmola, 2014).

The benefits of an entrepreneurial mindset should not be confined to a few innovative risk-takers. Gergen and Vanourek in their book on 'Life Entrepreneurs: Ordinary People Creating Extraordinary Lives' indicates the important twist on entrepreneurial thinking. The entrepreneurial mindset is one that is awake to new opportunities, brings creative solutions to whatever opportunities are on the horizon, translates those opportunities into vision and then ultimately puts them into action (Gergen \& Vanourek, 2009). These reviews indicate that these aforementioned aspects and characteristics are highly valuable in many professional paths more precisely in the case of entrepreneurs, wherein one lead teams and organizations. 


\section{Objective}

To conceptually review and understand the new mindset of entrepreneurs towards creating global business development

\section{Methodology}

The entire research study is based on self-entrepreneurship experiences, open discussions with young women entrepreneurs and feedbacks during entrepreneurs' networking sessions and journal papers.

\section{Mindset}

We all have a fixed and changing behaviours, and it generates from our mindset blueprints and support us to create our results. As Money and You graduate (moneyandyou.com), the researcher learnt the concept behind the development process of mindset, wherein one can understand it through this figure indicated below:

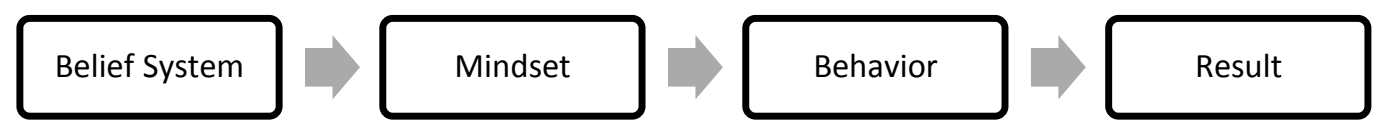

\section{Fig.1}

Our mindset is the hidden mechanism that showcases us opportunities and ignites our real ambition, engaging our strengths in ways that enable us to exhibit and thrive.

\section{Entrepreneurial Mindset}

A mindset is derived by belief system, overall belief pattern, assumptions, experiences and knowledge that we use to process information, drive our decisions, and guide our behavior.

An entrepreneurial mindset is a unique set of beliefs, experiences, knowledge, and thinking processes that drives entrepreneurial behavior. An entrepreneurial mindset tends to:

- Believe in their own capability to create their future and influence by their own experiences, empowering themselves to take ownership of their lives.

- Possess persuasive goals that keep them complete-focused and naturally motivated, driving themselves to be self-directed, action-oriented, and highly engaged. 
- Have an optimistic approach of risk events and see challenges as potential opportunities, become highly resilient, resourceful, and solutionoriented even within uncertain conditions, even in resourceless environment.

- Be lifelong knowledge gaining with a focus on new-experiments as learning opportunities to test new ideas, develop curiosity, creativity, and innovative thinking;

- Display a high-level of trust level, understanding that following through on easy solutions can lead to hidden opportunity.

- Have a clear vision, being other-focused and understanding that someone creates value by solving problems for others.

- Surround themselves with a focused community of positive influencers and critical problem solvers.

An entrepreneurial mindset can be developed and enhanced through real world entrepreneurial challenges and experiences. Also, to cultivate the entrepreneurial mindset, we must create entrepreneurial learning experiences within organizations, networks, and communities.

\section{New Mindset of Entrepreneurs with New Methods of Entrepreneurship}

\section{New Mindset of Young Entrepreneurs}

Excited for Well-Designed Future - in current time young entrepreneurs are more prepared and focused to create their well-designed future. Most of young entrepreneurs are starting their entrepreneurship journey with complete learning of start-ups according to their own passionate work.

Passion with Profit approach - Today's youngsters believe on their own passionate skills and prepare themselves to generate profit from their own passion. For doing that, they are always ready to learn from business mentors.

Innovative, Focused and Concentrate Mindset- exploring the new business ideas, asking the right questions, challenge accepting mindset with optimistic approach and being inquisitive or curious.

Clear Mindset with Long Term Vision and Mission - reinventing themselves on various situations (check, their goals are still the right one for them and adjust it if necessary) by being comfortable with ambiguity, uncertainty and variety. Moreover, the trusts to create short-term and long-term road map with clear mindset through creative experimentation. Also, young entrepreneurs believe that the failures are the process of finding success. 
Solution Developers According to Current Need - looking outwards as well as inwards. Developing solution at various business problems and focusing on current need of business environment.

Leadership Approach Instead of Ruling Approach with Resources - young entrepreneurs are adopting people-focused behaviour instead of people-ruling behaviour by creating business ethics with social responsibility.

Focused on Image and Personality - they have clear mindset with their own strategies, values and aspirations. Moreover, their image and personality are the most powerful drivers of what they want to achieve. It also helps them to identify, understand and use them as growth fuel to drive their actions, maintain momentum and increase their chances of success.

Believe to Take and Try New Business Techniques - trying many new business techniques, like capital mechanism instead of market mechanism, crossing the local limits and trying for global market, increasing the business potential by using online platforms, B2B (business-to-business) approach, global network and connections, focusing on more effective and easy products.

Technology Focused Mindset - concentrating on new technologies in business. Searching and continuous learning mindset in area of advanced technology tools to apply it effectively in their ongoing business and for their future business plans.

\section{New Mindset of Women Entrepreneurs}

Women entrepreneurs have been recognized as major participants in the field of entrepreneurship. They have established themselves as 'womenpreneurs' or 'womenopreneurs' with new mindset of success and are playing a major role in business world by removing many out dated theories, old-fashioned ideas and obstacles. Moreover, they have created a valuable identity for them in this male dominated world. Womenpreneurs set a lesson and male competitors are now recognizing the capabilities of a successful female entrepreneur.

\section{New Approach of Women Entrepreneurs with Collaborative Mindset}

The collaborative mindset of womenpreneurs is supporting them to achieve their success in all desire fields. The researcher found most of women entrepreneurs with new mindset of support and collaboration with each other. Self-awareness and connect themselves with others accordingly, large scale of social media interaction, greater need to depend on each other for support have led to the growth of womenpreneurs communities. Womenpreneurs communities are formed at all levels from district to national and even international levels, to bring together ideas and innovation for better growth and development. Women entrepreneurs has the strong 
new mindset that business people always ready to accept the collaborations and learn from each other to establish a stronger business enterprise, better opportunities, more growth, and profits.

\section{Determined Mindset and Stay Focused on the Mission}

Women entrepreneurs are always strong goal achievers. The mission that they fix in their mind they determined to complete it. Collaborate with people who have a common mission and common ideas. It makes the easier path for them to achieve their set goals and there are better chances of the partnerships succeeding. Also, having a clear vision and mission lead them back to the right path when distractions and other opportunities attempt to lead them away. They have a strong mindset of "If you are good at what you do, then there will be many doors that will open and many opportunities you will receive".

\section{Entrepreneurship with other Responsibilities}

Many women entrepreneurs are using many advance technologies to achieve their goals and complete their mission. They are working from home with their other responsibilities by using video conferencing as the primary communication method, online business techniques, e-commerce business tools and many more new business tools.

\section{Developed Mindset to Drop all Fears}

Fear of failure can be a debilitating factor in women's life and performance as a women entrepreneur. Women accepted this fact and developed their mindset to handle their fear face to face and defeat it. Also, to draw themselves out of the comfort zone and take challenges, take risks and go after success. The new mindset of womenpreneurs is coming out of the comfort zone and working wisely with confidence, which is best way to create new opportunities and to overcome fear of failure.

\section{Established New Innovative Business Tools}

Women entrepreneurs developed new innovative tools of business which are supporting to communities. They converted their passion into profit. They choose their passion as their earning tool. Many types of cultural, professional and social activities came up through women entrepreneurs.

\section{New Mindset of Global Entrepreneurs}

Global entrepreneurs require thinking and acting globally from inception. The researcher summarizes the principles of global entrepreneurship mindset and 
retraces the entrepreneurial journey as a global woman entrepreneur. It is a greater appreciation that how early and rapid globalization can increase the chances of success. Beyond knowledge acquisition and strategic development, a key element of this journey was a changing mindset that was necessary to fully embrace the global approach. Most entrepreneurs are comfortable to start their business to address the needs of a local market. Their common mindset is that they can fine-tune their market offers, planning and internal operating systems according to local needs. Foreign expansion occurs only once the company is sufficiently large and mature and has learned how to serve the needs of the local market. Global entrepreneurs changed the mindset, they allowed themselves to define and act on global opportunities at an early stage in their company's life cycle. Their mindset is focused on global approach. This is based on entrepreneur's own gradual change in mindset, which began with lessons from self-entrepreneurial experience even before status-quo as global woman entrepreneur. According to researcher, the new mindset of entrepreneurs to become the global entrepreneurs is based on following points:

\section{Install a Global Mindset throughout the Company from Starting Point}

Focus on global opportunities from the beginning, 'local' is a small part of 'global'. Initiate a strong discussion and planning of global opportunities with local opportunities. Ideally, a global mindset should drive the enterprise from the start, including all of the founders and employees. Without a global mindset, it is tough for any organization to serve foreign clients and foreign sources. The researcher as a woman entrepreneur commenced the entrepreneurship journey in 2009, wherein it was very clear with all global business strategies for long-term goals, which is currently getting achieved.

\section{Create International Network and Connections}

A global business mindset requires a global network of connections can be leveraged to find customers, clients and partners. In that case, many immigrants to a country have a significant advantage over domestic entrepreneurs who have rare international experience, knowledge, or connections. It is important to overlook at different possible groups. For instance, new immigrants, foreign chambers of commerce, other officials from foreign embassies, universities, international associations, global business clubs, international referral groups, etc. They become critically important during the start-up phase of any company to reach globally. Similarly, hiring employees with international experience can provide advantage and exposure. Moreover, the New mindsets of global entrepreneurs needs to overview their current global networks and create a strategy to form new networks to pursue a series of global opportunities. As part of researcher's internationalization planning, the global network of skilled women, passionate entrepreneurs and potential customers have been created. Furthermore, through creation of Grace Ladies Global Club, on one side a huge network of ladies and 
worked effectively on womenpreneur strategy have been roped in. Interestingly, at the other end the entrepreneur connected with many international organizations and global clubs to build the global market for the company's products and services.

\section{Optimistic Mindset to Face any Challenge or Situation}

Most of global entrepreneurs get their growth with optimistic mindset. The optimistic mindset can be an asset to an entrepreneur but it can also be the reason of failure because it can lead the entrepreneur to create a wrong direction of business that cannot succeed. Moreover, huge aspirations propel the entrepreneur to try a large global business too soon. The right strategy is to go further with a planned global business structure or roadmap. For any company, the problem must be clear and well defined and try to find out a clear solution - ideally with a quantifiable return on investment for customers who pay for your solution. With this same mindset, the researcher and her team are continually working to define and refine the problems that we solve for our customers and clients.

\section{Advance Market Strategy for Foreign Customers \& Clients}

A minimum viable product or service is an offer that generates revenue for the company and that motivates customers to provide feedback and recommend it to other potential customers (Moogk, 2012).

Many entrepreneurs tend to spend too much time to create, modify, and enhance a product or service before it is ever seen by a customer. A global entrepreneur should use the minimum viable product to leverage each foreign customer to earn money, receive customer's feedback on what changes or modifications are required according to their experience and ask customers for referrals. The researcher has studied and applied the principles of referral selling because it is one of the most accepted sales strategies for best global approach.

\section{Leverage the Assets of Well-established Networking Organizations}

Leverage the assets of established organizations with global operations to gain access of foreign customers and clients. These assets include technology platforms, internet forums, brands and open source communities. Large scale global business platforms always have a huge global users, developers and partners. The reason being they are localized with many different languages. Also, the open source software provides important infrastructure capabilities such as e-commerce, localization and give access to diverse, active and global communities of users. 


\section{Develop a Global Business Model}

New mindset of global entrepreneurs is much more than an export strategy, they believe to develop a business model where they acquire and sell products and services in different geographies. Furthermore, the new possibilities include software-as-a-service (SaaS), infrastructure-as-a service (IaaS), platform-as-aservice (PaaS) or backend-as-a-service (BaaS). This is experimented with the researcher's Singapore based company named Professional Skill Development Hub (PSD-HUB), wherein it has been decided at the beginning of start-up, that it would make the business model base on a cloud-based software-as-a-service. Also, Software-as-a service business model fit our global aspirations.

\section{Innovation of New Techniques in Entrepreneurship}

\section{Gain Guidance Approach to get Success}

The starting or owning a business can be stressful, frustrating and even maddening. Many entrepreneurs are not able to do masters of business (educational degree) or any family business backgrounds. Hence, in that case entrepreneurs are using the new technique of learning from certified experienced mentors or coaches. They choose someone who can guide them to deal with obstacles, offer a different perspective, solutions and be the person to keep their ego in control. They just find one who understands them and create a balanced mentor-mentee relationship.

\section{Global Leadership Learning}

Perhaps not surprisingly, leadership is also one of the major areas, wherein entrepreneurs excelled. Entrepreneurs are applying global leadership technique to spread their business globally. They are trying global leadership to gain the attention during networking and international gatherings.

\section{Goal Orientation}

Goal orientation is defined as energetically focusing efforts to achieve a goal, mission, or objective which closely paired-up with leadership, as it is described above. It is another new technique of success for entrepreneurial-minded people. Most of the entrepreneurs generally agreed upon: "I am known for overcoming significant obstacles to achieve my goals," or "I am most productive when working closely with others and support them to achieve their goals". It is quite important for entrepreneurs to have a strong sense of what their goals are because their product or service depends on it. 


\section{Develop Advance and Professional Communication Style}

The final identifying technique of entrepreneurship is a mastery of interpersonal skills, whereas the glue that holds the other skills together. It includes effective communication, building rapport, relating well to all people from different backgrounds and various communication styles. The new mindset says, without interpersonal skills, an entrepreneur would be limited to relating only to those who share their exact communication style and finally restricting their ability to convey their vision and mission.

\section{Advance Learning of Money Relationship}

Money relationship is a new innovative learning by entrepreneurs that are shifting them from their negative, damaging thoughts into a positive wealth creating mindset and give them the money management habits with positivity. It creates "Money Moves" for them to take risks.

\section{Online Business Approaches\& Trends}

\section{Search Engine Optimization (SEO)}

SEO is the process of making a site more visible in search engines, so it provides more traffic from people searching for the products or services we offer. It is an effective online tool, which entrepreneurs are using on priority.

\section{Conversion Optimization}

Most of these strategies aim to get more people on any business website. The conversion optimization helps to entrepreneurs to ensure them to get more value out of each and every visitor by maximizing their rate of conversion.

\section{Social Media Marketing}

Social media marketing has a significant potential in building and nurturing a social media audience. Hence, entrepreneurs are using it effectively in their new business strategies.

\section{Email Campaign}

The email campaign is a sequence of marketing efforts that contacts multiple recipients at once. Email campaigns are designed to reach out to subscribers at the best time and provide valuable content and relevant offers. It is the new style of email marketing, which has an astounding potential for ROI because it costs almost nothing to execute. Start collecting subscribers from the existing customer base, 
social media followers and other new connections. For instance, even a simple content newsletter encourages repeat traffic to any business site, facilitate more engagement with business brand and keep that brand top-of-mind with audience.

\section{Suggestions}

The support extended to entrepreneurs is directly strengthening the backbone of economic development of any nation. This in turn provides jobs and new products or services that impact on many people's life. Moreover, the new mindset of a successful entrepreneur needs outside-the-box thinking to create a new business world. Anyone can start with a passion, but develop a successful business is the major challenge. The new entrepreneurial mindset should always be unique, creative, balanced, communicative and highly motivated to succeed. In furtherance, the learning of new and advance entrepreneurial mindset concepts and keys supports to get early success and facilitate to build a thriving business. Having the new success mindset as an entrepreneur will enable you to deal more effectively your business. After knowing all new and advance concepts you will be able to think and react like a true entrepreneur. It is to be noted that once you become more confident with new success mindset, you can move further with a planned roadmap. According to this research study and experiential learning, some of the following suggestions can support the entrepreneur to initiate and run a successful business model with new mindset:

\section{$>$ Find out your real passion to initiate your business}

Many entrepreneurs start their entrepreneurship journey to see the market trends or what others are doing in their business. In that case, they forget about their own passionate skill with their own positive mindset. It is quite important to understand that an entrepreneur cannot remove passion from success process. Hence, it is suggested to create a clear mindset to find out real passion through which you can convert into profit anytime.

\section{$>$ You need only your own approval to become an entrepreneur}

The common process to live a life is to learn and apply it by you. It is since one's childhood they have learnt many things from surroundings, created blueprints in the minds and applied it in their lives. The same process has to be applied to become an entrepreneur. Most important is self-approval to initiate business of your choice.

\section{$>$ Develop new mindset to draw your own future with strong believe and planned roadmap}

The new mindset has to draw a future roadmap with strong belief that it should be a prior process for any entrepreneur. It is something like a ladder to climb at your 
highest business peak successful, wherein the new mindset of entrepreneur is to be focused and determined. However, in case you believe you can get better and do other things, whereas growth mindset will enable you to accomplish more.

\section{$>$ Walk three steps further, think all possibilities}

According to current time and need, you always have to think three steps further action and looking at all possible opportunities for better gain. Ask yourself, "What is happening right now?" and "What will happen three steps further from the action which I am taking today?"

\section{$>$ Fix an incredible vision and mission for your business}

Clear vision always gives you strength to grow with big achievements. Fix mindset with clear vision and mission supports you to cross through all obstacles positively. "You don't climb straight from nothing to something big. You hit an obstacle, climb over it and reach the next level of the plateau. You cross the line again, cross another obstacle and climb to the next level again. The more you do that, the more you will look back and realize how far you've come. It is all about overcoming each obstacle as it hits, and not giving up." Brian Smith, Founder of UGG Boots.

\section{Conclusion}

Entrepreneurship is an ever-changing research field. Entrepreneurship is essential for rapid and sustained economic growth and development of any nation. The chapter summarizes the new mindset of entrepreneurs to create a new business world, wherein the research focused on new and most used techniques and knowledge in business, tools of motivation, attention and new technologies. Also, the ideas to create a successful business model, identity and emotions in the entrepreneurial process. Also, the chapter showcased the complete understanding of new mindset of young entrepreneurs, women entrepreneurs, global entrepreneurs and innovation of new techniques of entrepreneurship by entrepreneurs. Thus, developing a 'New Entrepreneurial Mindset' which is very much indispensable for success and future growth of any entrepreneur in today's context. Hence, the understanding of new mindset of an entrepreneur is drawn to new opportunities and challenges, quick solution finder in difficulties, always prepare to take great risks, welcoming changes, take the actions persistently, pursue new initiatives, focusing on global market and seeing the big business model.

\section{References}

Aruwa S. A. S. (2004). The Business to Entrepreneur: A Guide to Entrepreneurial Development, Journal of Development of Business Administration, Vol.2, No.1, pp.112-122. 
Drucker, P. F. (1970). Technology, Management \& Society, Harper \& Row Publishers Inc., New York, USA, 209p.

Dweck, C. S. (2012). Mindset: How You Can Fulfil Your Potential, Constable \& Robinson Ltd., London, UK, 160p.

Gergen, C. \& Vanourek, G. (2009). Life Entrepreneurs: Ordinary People Creating Extraordinary Lives (J-B Warren Series Book 142), Jossey-Bass Inc., USA, 261p.

European Commission (2005). Proposal for a Recommendation on Key Competences for Lifelong Learning, Com (2005) 548 Final, Brussels, Belgium, pp.1-18.

Haidar, J. I. (2012). The Impact of Business Regulatory Reforms on Economic Growth, Journal of the Japanese and International Economies, Vol.26, No.3, pp.285-307.

Moogk, D. (2012). Minimum Viable Product and the Importance of Experimentation in Technology Startups, Technology Innovation Management Review, Vol.2, No.3, pp.23-26.

Moses, C. L. \& Mosunmola, A. (2014). Entrepreneurship Curriculum and Pedagogical Challenges in Captivating Students' Interest towards Entrepreneurship Education, Research Journal of Economics \& Business Studies, Vol.4, No.1, pp.1-11.

Valerio, A., Parton, B. \& Robb, A. (2012). Entrepreneurship education and training programs around the World - Dimensions for Success. The World Bank, Washington, D.C., USA. 264p.

\section{Bibliography}

Bennett, R. (2006). Business Lecturers' Perception of the Nature of Entrepreneurship, International Journal of Entrepreneurship Behaviour and Research, Vol.12, No.3, pp.165-188.

Buchholz, R. A. \& Rosenthal, S. B. (2005). The Spirit of Entrepreneurship and the Qualities of Moral Decision Making: Toward a Unifying Framework, Journal of Business Ethics, Vol.60, No.3, pp.307-315.

Pihie, L. A. Z. \& Sani, A. S. A. (2009). Exploring the Entrepreneurial Mindset of Students: Implication for Improvement of Entrepreneurial Learning at University, Journal of International Social Research, Vol.2, No.8, pp.1-6. 
Shepherd, D. A. (2003). Learning from Business Failure: Propositions of Grief Recovery for the Self-employed, Academy of Management Review, Vol.28, No.2, pp.318-328.

Soyibo, A. (2006). The Concept of Entrepreneurship, Journal of Business and Organization Development, Vol.5, No.1, pp.54-56.

Thompson, J. L. (2004). The Facets of the Entrepreneur: Identifying Entrepreneurial Potential, Management Decision, Vol.42, No.2, pp.243-258. 